\title{
The mediating role of brand credibility between social media influencers and patronage intentions
}

\author{
Muneer Alrwashdeh ${ }^{a^{*}}$, Hussam Ali ${ }^{b}$, Abdullah Helalat ${ }^{c}$ and Dina Ahmad Awad Alkhodaryd
}

${ }^{a}$ Assistant Professor of E-marketing, Faculty of Business, Department of E-marketing, Irbid National University, Irbid, Jordan

${ }^{b}$ Assistant Professor of marketing, Faculty of Business, Department of marketing, Middle East University, Amman, Jordan

${ }^{c}$ Assistant Professor of Tourism and Hospitality Management Department of Business Administration, Business School, Al-Ahliyya Amman University,

Amman, Jordan

${ }^{d}$ Assistant Professor of Bsiness, Faculty of Business, Department of Business, Middle East University, Amman, Jordan

\section{H R O N I C L E}

Article history:

Received: October 28, 2021

Received in revised format: No-

vember 28, 2021

Accepted: January 18, 2022

Available online: January 182022

Keywords:

Social Media Influencers

Brand credibility

Ewom

Repurchase intention

Patronage intentions

\section{A B S T R A C T}

This study aims to examine how Social Media Influencers (SMIs) influence patronage intentions (PI) through the influence of mediation on the brand credibility (BC) in the electronic devices sector in Jordan. Furthermore, the data were obtained by an online questionnaire based on Google Forms and a total of 315 followers in Jordan using an appropriate sampling method. structural equation modeling using Smart PLS 3 was used to investigate the relationships between SMIs, brand credibility, and patronage intentions (PI). The results indicated that SMIs directly influence PI and BC. BC Partially mediates the relationship between SMIs and PI. Research limitations in this study focus on a single sector electronic device at a specific location in Jordan. Future research may conduct cross-cultural studies to improve the generalizability of the present research findings.

\section{Introduction}

A few years ago, there was a huge increase in the number of followers and the number of users of these platforms is evident when compared over time. In 2017, less than half a billion people used social networking sites worldwide, and by 2019 , this percentage had increased to more than 3.5 billion users worldwide, which contributes to about 45 percent of the world's total population (IBEF 2020). Moreover, the latest update reveals that digital growth rates are increasing despite the spread of the COVID-19 virus for more than a year and a half and that the massive increases in reliance on social media use remain high as we move into the second half of 2021 (Digital, 2021). Subsequently, many users of social media platforms today use their smartphones apart from using any other computer (De Veirman, \& Hudders 2017). Accordingly, social media platforms have become for many users a basic need in their daily life as usual (Hallanan, 2018). Hence, social media platforms have also become an important marketing platform in our lives now and have become a popular way for brands to achieve their marketing goals and enhance their brand value (Heitmann, \& Herrmann 2007). Moreover, many social media sites are very popular all over the world, especially in Jordan, including Facebook, YouTube, Instagram, Twitter, Snapchat, etc. (Kaur \& Singh, 2007; Ahluwalia, 2018). From the age of 18 to 35, young people in Jordan use the Internet daily at a rate of $96 \%$, and this group uses the Internet extensively, as the number of hours reaches 5 hours per day, knowing that this study was conducted to identify the cultural culture. And the media trends of Jordanian youth, just as there is a percentage of Jordanians who use the Internet on average, as the number of hours they use the Internet is less than an hour per day, and there is a category of up to $1.7 \%$ (Statista, 2020; Arora \& Sanni, 2019; Dinev \& Hart, 2004).

* Corresponding author.

E-mail address: Malrwashdeh@inu.edu.jo (M. Alrwashdeh) 
Furthermore, with the development of social media platforms, the strategies of many companies also changed about public relations and advertising, as well as the phenomenon of the interest of influencers who appeared to occupy a privileged position in society and try to play an important role that became closely related to the flow of information (Trivedi \& Trivedi, 2018). Despite the criticism, influencers have become one of the most influential tools in various fields that are used in many areas, whether it is in international issues or even in multiple areas, including marketing advertising. (Coley and Yancy Parks, 2019). Moreover, the massive increase in the number of influencers has led to a massive increase in the number of followers, which has given rise to many issues, not the least of which is trustworthiness (Lou \& Yuan, 2019). Additionally, many brands are hiring celebrities to support their brands through both traditional and non-traditional forms like influencers and they are widely known users who have become popular across all these platforms due to their knowledge and competence in a particular topics like meals, style, technology, song Games (Kumar et al., 2020). Moreover, brands have been recruiting influencers on social media platforms for some time through a related field, and as a result, when influencers promote businesses related to their field, consumers can easily believe and accept the influencers' opinions (Freberg et al., 2011). Today, social media recruitment for SMEs has developed as an important and successful tool for businesses. (Judy et al., 2007). Moreover, for companies trying to grow their customer base and change those who are obsessed with completely loyal customers, this style of marketing both goods and services is incredibly beneficial in establishing long-term relationships with consumers (Kumar et al., 2018). Influencer marketing can help organizations of all sizes achieve their goals. It may be used to promote a new product, increase online or offline sales of existing products, or even create a positive reputation in the market, people may not notice a company's post on their social media accounts since it is considered a pure advertisement, but an influential recommendation or opinion may be noticed. Since it is an influential source, it is not an advertisement (Lou \& Yuan, 2019; Trivedi 2018; Chakraborty \& Bhat, 2018).

The purpose of this research is to investigate the role of BC in modifying the relationship between SMIs and PI. For this reason, the research evaluates information on quality, $\mathrm{BC}$, and likeability as part of the purchase intent study. Through the presented model, the results provide theoretical insights into SMIs and add to the literature. Understanding the sub-dimensional factors on SMIs that influence customers' purchase intentions may help marketers use SMIs as a new strategy.

\section{Background}

\subsection{SMIs}

Social media influencers are a very broad term that includes different types of social media directions that the brand may take in advertising issues (Aaker \& Vohs, 2012; Park \& Eisingerich, 2016). According to Aaker and Vohs (2012); Park et al., (2016) with the widespread use of the Internet in daily life and the supremacy of social networking sites on the scene, the socalled "influencers" phenomenon has grown to the point where it is no longer a matter of using famous people and stars of society, or even international stars such as football players or movie stars, to promote a product or a service. Rather, these influencers have become an economic phenomenon, with the total value of marketing through them increasing from 1.7 billion dollars in 2016 to around ten billion dollars last year, with expectations that it will reach 12.8 billion US dollars this year (Kaur \& Singh, 2007; Ahluwalia, 2018). Besides that, once we're in the research of effect on buyers, the meaning of thought leaders is a person or something that affects another individual, although, in the marketing field, we call it an individual who would have the ability to influence prospective customers of a service or product besides promoting or recommending items on Digital networking, in which an influencer adds serious credibility to their brand (Karjaluoto \& Kiuru, 2016).

$\mathbf{H}_{1}$ : SMIs positively impacts a consumer's PI.

\subsection{Information Quality}

One of the most significant issues with influencer marketing is determining the correct influencers, as social bots and the purchase of phony followers create mistrust not just between the influencers and the customers (Pina et al., 2019; Raji et al., 2020). Several studies show that an increasing number of companies are turning to influencer marketing, with approximately 63 percent of large companies planning to increase their budget for influencer marketing this year, and large companies' budgets for influencer marketing are growing in tandem with the continued and escalating popularity of social media (Kim $\&$ Ko, 2012; Taylor et al., 2011; Gautam \& Sharma, 2017; Costanzo \& Goodnight, 2005). The amount of total marketing expenditure given to influencer marketing is presently believed to be about $12 \%$, indicating large corporations' faith in the success of this marketing approach despite the issues surrounding it (Gass \& Seiter, 2011). Through, explained that influencer marketing often accomplishes greater success than traditional marketing methods, particularly paid to advertise, even though clients realize that tv ads, for instance, is a paid ads material, so although influencer marketing, takes advantage of the already existing relationships and credibility among influencer marketing and their followers, as well as display a higher level of credibility (Hayes \& Carr, 2015; Ohanian, 1991). With all of this, the process of integrating influencers into the company's overall marketing plan is a real challenge for most companies, so it is sometimes the main reason for marketing efforts in this field underperforming. The brand must have a thorough awareness of its target demographic, as well as a well-defined aim. It is essential to select individual influencers as the best and appropriate options to engage within branding strategy (Hu et al., 2003; Dao et al., 2014). 
$\mathbf{H}_{2}$ : The information quality positively impacts the credibility of an influencer.

\subsection{Likability}

A consumer is drawn to the caller's delight, or even the communicator's friendliness/likability (Desarbo \& Harshman, 1985). A positive endorser's likability boosts credibility, Ewom, and buy intent (Taylor et al., 2011; Lou \& Yuan, 2019).

H3: Likability positively impacts the credibility of an influencer.

\subsection{Entertainment}

People utilize social media sites for a variety of reasons (De Vries et al., 2012; Leung, 2013; Godey et al., 2016; Chen \& Lin, 2018). Usage of social media texts rely on their perception of the value of the advertisement and the informational value of the publication, on the one hand, with the value of its entertaining input, credibility, and ultimately influencing the purchasing intentions of consumers through electric word of mouth (Gautam \& Sharma, 2017; Kim \& Ko, 2012; Dodoo, 2018). Furthermore, the perceived entertainment value of the content posted by the influencer may influence credibility and PI.

H4: The entertainment value positively impacts the credibility of an influencer.

\subsection{The credibility}

According to O'Keefe (1990), Credibility is "a judgment made by a perceiver regarding the credibility of the caller", which results in positive communication features that affect the recipient. The reliability of the provider is also in this of the message (Ohanian, 1990). Next, the credibility of the influencer in the social media platform influences buyers' buying intent and brand attitude) La Ferle \& Choi, 2005; Hayes \& Carr, 2015; Chin et al., 2020). Furthermore, in the context of traditional celebrity endorsement, supporter credibility has been proven to serve a mediating role between the endorser's attributes and customers' buy intent (Wang et al., 2017; Djafarova \& Rushworth, 2017). As a result, we expect the influencer's reputation to buffer the links between his facilities and consumers' purchasing intentions.

Hs: Credibility of the influencer positively impacts a consumer's PI.

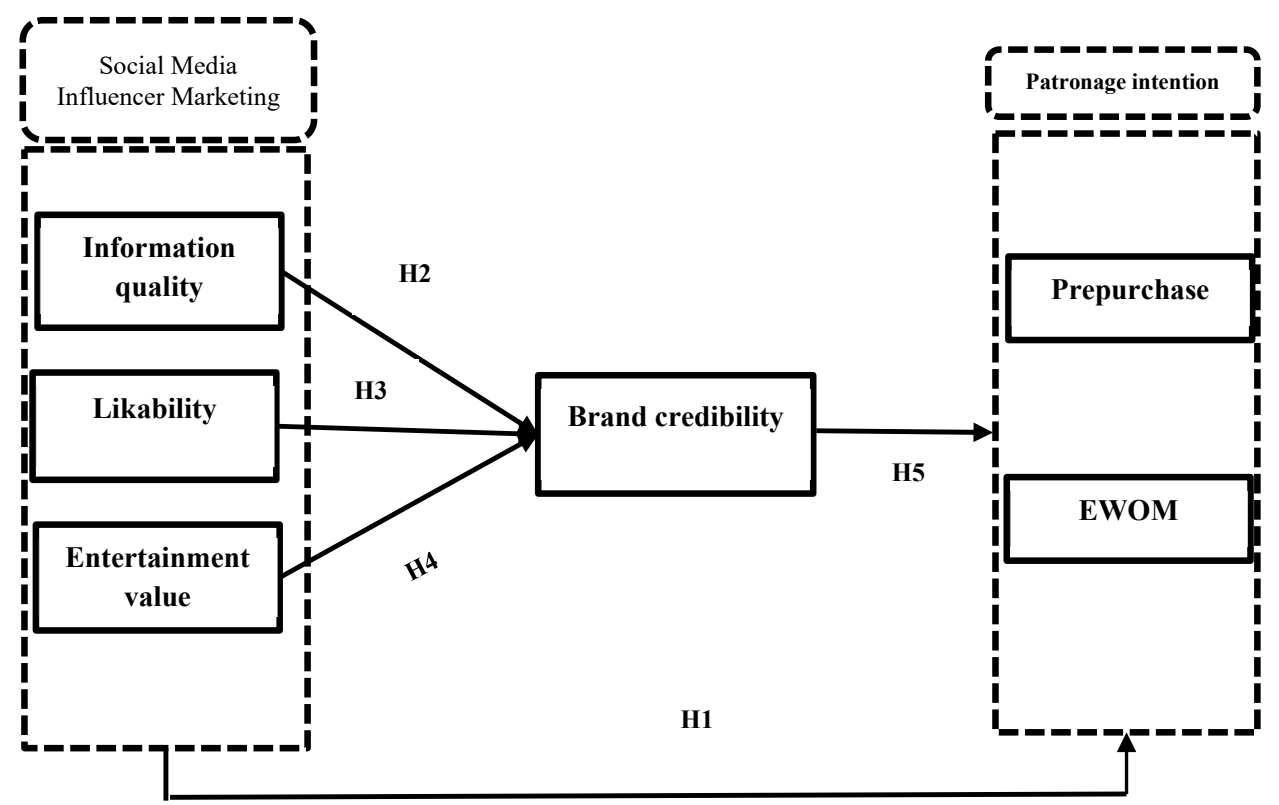

Fig. 1. Research Model

\section{Method}

This section provides the data for this research was collected online via Google Forms to users of electrical appliances in Amman, Jordan. Also, the method used a quantitative technique. The study only covered individuals who were active on social media. A survey with filter questions was given to participants, with 26 questions asking whether respondents followed any SMIs they utilized, as well as selecting one or two of their favorite SMIs. Thus, the research community is defined as all 
Jordanian followers. Followers who are on social media platforms and have an active account for one or more of these social sites, such as social networking sites (Facebook, Twitter, Youtube, Instagram), are the only ones who may engage in this search, and this was a requirement. Data was collected using an appropriate sampling approach, with a sample size of 500 followers. This was established based on the number of questions contained in the questionnaire and the number of questionnaires required for each item for a consistent statistical analysis (Hare et al., 1998). 185 questionnaires were returned after utilizing the electronic channels Google Forms, and the response rate ( 73 percent) was rather high due to the number of questionnaires utilized being accurate (350) of the returned surveys. A 5-point Likert Adaptation Scale of "from strongly agree to strongly disagree" from previous research studies was used to build the search tool. Its purpose was to measure the entertainment value (Voss et al., 2003), Quality of information derived from a study by Cheung et al. (2012), and Entertainment Value the credibility of the source mentioned from a study by Xiao et al. (2018). Purchase intent was measured by adapting the scales from studies (Kumar, 2011).

\subsection{Measures, software program}

Smart PLS 3 program was used in the paper to examine the research hypotheses and to analyze the data in this investigation (Chen 1998). It was chosen for data processing primarily because small sample sizes are more acceptable for evaluation (Chen et al., 2003). A two-step evaluation technique Measurement and structural models were used. A range of measurements was made to regulate the reliability and convergent validity, including mean-variance, extracted factor loadings, and composite reliability. Factor loadings are being used to determine the significance \& relationship value of each Survey question variable as a perceived indication. A higher load value might help indicate the size of the factors. The composite reliability measure is often used in analyzing dependent. CR is linked because it gives detailed relevance to the combined formula through the application of loading factors. AVE returns the average amount of variation in a file. The variable that describes the underlying construction. When the legality of discrimination is put into question. Then, Extracted Average Variance can be used to check the convergence of all factors when there is more than one. As shown in Table 2, our questionnaire reliability and close validity test results indicate good reliability and near validity scores.

\section{Results}

\subsection{Reliability and validity}

The search model was evaluated using SMART PLS 3, which is a structural modeling tool that is ideal for predictive models (Bentler \& Chu, 1987). We examined the metrics' reliability and validity before testing the hypotheses. Convergent validity, as measured by composite reliability (CR) and mean extracted variance (AVE), demonstrates how items are connected; in other words, whether they are of the same measurement or not. The lowest allowed number for CR is 0.70 , while the lowest accepted value for AVE is 0.50 (Fornell \& Larcker, 1981; Alrwashdeh et al. 2019).

Table 1

Reliability analysis for variables

\begin{tabular}{|c|c|c|}
\hline Construct & items & Cronbach's Alpha \\
\hline \multirow[t]{6}{*}{ (IQ) Information quality } & IQ 1 & \multirow{6}{*}{ (2) } \\
\hline & IQ 2 & \\
\hline & IQ 3 & \\
\hline & IQ 4 & \\
\hline & IQ 5 & \\
\hline & IQ 6 & \\
\hline \multirow[t]{4}{*}{ (like) Likability } & Like1 & \multirow{4}{*}{.834} \\
\hline & Like2 & \\
\hline & Like3 & \\
\hline & Like4 & \\
\hline \multirow[t]{6}{*}{ (EV)Entertainment value } & EV1 & \multirow{6}{*}{.841} \\
\hline & EV2 & \\
\hline & EV3 & \\
\hline & EV4 & \\
\hline & EV5 & \\
\hline & EV6 & \\
\hline \multirow[t]{6}{*}{ (CB)Credibility brand } & CB1 & \multirow{6}{*}{.914} \\
\hline & CB2 & \\
\hline & CB3 & \\
\hline & CB4 & \\
\hline & CB5 & \\
\hline & CB6 & \\
\hline \multirow[t]{3}{*}{ Repurchase } & Rep1 & \multirow{3}{*}{.738} \\
\hline & Rep 2 & \\
\hline & Rep 3 & \\
\hline \multirow[t]{3}{*}{ Ewom } & ewom1 & \multirow{3}{*}{.902} \\
\hline & ewom2 & \\
\hline & ewom3 & \\
\hline
\end{tabular}


Table 2 shows that the CR for each variable is more than $0.8(0.815 \mathrm{e} 0.890)$ and the AVE for each variable is greater than $0.50(0.591 \mathrm{e} 0.745)$, indicating that convergent validity has been reached. The loading factor's suggested level is 0.70 , and all loading factors in this research are more than 0.70 . See Table 2. Furthermore, the discrimination's validity was examined to see whether the measurement did not reflect any other measurement. For appropriate discriminant validity in this analysis, each of the square roots of AVE must be greater than the other correlation coefficients (Fornell \& Larcker, 1981). Table 3 shows that the square root of AVE for each variable is bigger. Another correlation coefficient indicates that discriminative validity has been achieved. We check the values of the variance inflation factor to see if the multiple linear relationship problems exist (VIF). The VIF. values where each variable in the study was observed. The maximum probability estimate was then used to perform confirmatory factor analysis (CFA). TLI, GFI, AGFI, and CFI values should be greater than 0.90 for a good model. Hair, among other things. (1998) additionally mandated that the SRMR value be less than 0.1 (Kodik \& Brown, 1993). When the RMSEA value is less than 0.1, the model fit indications are considered satisfactory. The load factor for the two components was found to be less than 0.60 and was therefore ignored in further study. Cronbach's alpha was determined after deleting these two components, and each variable had an alpha value greater than 0.70. CFA, alpha, and factor loadings are shown in Table 2. The convergent and distinct validity were then tested (Bagozzi \&E dwards, 1998). The extracted mean-variance (AVE) and composite reliability (CR) values were both more than 0.5 and 0.7 . As a result, it is acceptable (Fornell \& Larcker, 1981). Table 2 shows the AVE and CR values for each variable. Furthermore, for each variable, the power to discriminate is calculated as the square root of the AVE value. The values that prove discriminatory validity are shown in Table 2.

Table 2

Convergent validity results

\begin{tabular}{|c|c|c|c|c|c|}
\hline Construct & Items & Factor Loading & Cronbach's Alpha & $\mathrm{CR}$ & AVE \\
\hline \multirow[t]{3}{*}{$\mathrm{BC}$} & BRD_1 & 0.767 & \multirow[t]{3}{*}{0.759} & \multirow[t]{3}{*}{0.811} & \multirow[t]{3}{*}{0.651} \\
\hline & BRD_2 & 0.723 & & & \\
\hline & BRD 3 & 0.888 & & & \\
\hline \multirow[t]{3}{*}{ Information quality } & IQ 1 & 0.840 & \multirow[t]{3}{*}{0.778} & \multirow[t]{3}{*}{0.842} & \multirow[t]{3}{*}{0.673} \\
\hline & IQ 2 & 0.912 & & & \\
\hline & IQ 3 & 0.887 & & & \\
\hline \multirow{3}{*}{ Repurchase } & Rep1 & 0.826 & \multirow{3}{*}{0.880} & \multirow[t]{3}{*}{0.779} & \multirow[t]{3}{*}{0.661} \\
\hline & Rep 2 & 0.720 & & & \\
\hline & Rep 3 & 0.734 & & & \\
\hline \multirow[t]{3}{*}{ Likability } & Like1 & 0.799 & \multirow[t]{3}{*}{0.887} & \multirow[t]{3}{*}{0.704} & \multirow[t]{3}{*}{0.713} \\
\hline & Like2 & 0.821 & & & \\
\hline & Like3 & 0.706 & & & \\
\hline \multirow[t]{3}{*}{ Entertainment value } & EV1 & 0.792 & \multirow[t]{3}{*}{0.883} & \multirow[t]{3}{*}{0.895} & \multirow[t]{3}{*}{0.729} \\
\hline & EV2 & 0.759 & & & \\
\hline & EV3 & 0.980 & & & \\
\hline \multirow{3}{*}{$\begin{array}{l}\text { Electronic Word of } \\
\text { mouth }\end{array}$} & ewom 1 & 0.788 & \multirow[t]{3}{*}{0.722} & \multirow[t]{3}{*}{0.801} & \multirow[t]{3}{*}{0.770} \\
\hline & ewom2 & 0.877 & & & \\
\hline & ewom 3 & 0.794 & & & \\
\hline
\end{tabular}

Table 3

Cross-loading results

\begin{tabular}{|c|c|c|c|c|c|c|}
\hline & $\mathrm{BD}$ & IQ & REPPUR & Like & $\mathrm{EV}$ & eWOM \\
\hline BD 1 & 0.767 & 0.105 & 0.494 & 0.166 & 0.316 & 0.515 \\
\hline BD_2 & 0.723 & 0.456 & 0.373 & 0.258 & 0.224 & 0.101 \\
\hline BD_3 & 0.888 & 0.585 & 0.251 & 0.292 & 0.585 & 0.484 \\
\hline IQ $\overline{1}$ & 0.121 & 0.840 & 0.383 & 0.198 & 0.139 & 0.392 \\
\hline IQ 2 & 0.282 & 0.912 & 0.565 & 0.299 & 0.332 & 0.338 \\
\hline IQ 3 & 0.446 & 0.887 & 0.595 & 0.143 & 0.201 & 0.401 \\
\hline Rep1 & 0.532 & 0.554 & 0.826 & 0.244 & 0.363 & 0.665 \\
\hline Rep 2 & 0.404 & 0.448 & 0.720 & 0.581 & 0.319 & 0.434 \\
\hline Rep 3 & 0.468 & 0481 & 0.734 & 0.332 & 0.315 & 0.319 \\
\hline Likel & 0.240 & 0.292 & 0.334 & 0.799 & 0.237 & 0.325 \\
\hline Like2 & 0.385 & 0.293 & 0.497 & 0.821 & 0.351 & 0.451 \\
\hline Like3 & 0.373 & 0.387 & 0.596 & 0.706 & 0.373 & 0.434 \\
\hline EV1 & 0.372 & 0.239 & 0.339 & 0.464 & 0.792 & 0.509 \\
\hline EV2 & 0.237 & 0.415 & 0.398 & 0.342 & 0.759 & 0.472 \\
\hline EV3 & 0.478 & 0.496 & 0.437 & 0.291 & 0.980 & 0.210 \\
\hline ewom1 & 0.244 & 0.430 & 0.420 & 0.503 & 0.303 & 0.788 \\
\hline ewom2 & 0.583 & 0.547 & 0.534 & 0.382 & 0.481 & 0.877 \\
\hline ewom 3 & 0.362 & 0.434 & 0.525 & 0.449 & 0.542 & 0.794 \\
\hline
\end{tabular}

To examine the relative degree of convergent validity, we employed factor loading, variance extraction, and reliability (consisting of Cronbach's alpha and composite reliability) as markers. Both constructs have reliability and composite (CR) values greater than 0.7, indicating internal consistency between numerous construct measurements (Hair et al. 2012). Cronbach's alpha values are above the pathological value of 0.7 (Gefen \& Boudreau, 2000), and the validity of the composite hypotheses range from 0.704 to 0.895 , as shown in Table 2. Furthermore, all extracted mean-variance (AVE) values ranging from 0.651 
to 0.770 included a criterion describing at least $50 \%$ of the extracted variation between a set of items, underlying the underlying construction (Falk \& Miller 1992). As a result, measures of evaluating structures are thought to achieve convergent validity. Table 4 demonstrates that the discriminative validity imperatives are met because all AVE values are greater than the quadratic correlation concerning the scaling model fixtures (Hair et al. 2012). While the AVE value is greater than 0.5, it is suggested that the construct causes at least $50 \%$ of the measurement variance. The discriminant value was estimated using partial least squares (SmartPLS v3.2.6). Factor loadings and cross-loadings are shown in Table 3. A thorough examination of cross-loading and loading reveals that all scaling elements are usually loaded on their underlying installations rather than on others. Table 4 also includes the AVE analysis. The table's bold diagonal lines represent the square root of the AVE results. The unloaded diagonal components, on the other hand, represent the correlations between the fixtures. The table shows that the square root of the AVE values ranges from 0.737 to 0.902 , which is greater than the suggested value of 0.5. The AVE is significantly larger than any inter-structure correlations for any structure, implying that all constructs have a higher variance.

Table 4

Fornell-Larcker scale

\begin{tabular}{|c|c|c|c|c|c|c|}
\hline & $\mathrm{BR}$ & IQ & REPPUR & Like & $\mathrm{EV}$ & EWOM \\
\hline BD & 0.855 & & & & & \\
\hline IQ & 0.152 & 0.902 & 0.404 & 0.299 & 0.526 & 0.250 \\
\hline REPPUR & 0.247 & 0.591 & 0.796 & 0.288 & 0.431 & 0.578 \\
\hline Like & 0.536 & 0.276 & 0.329 & 0.872 & 0.311 & 0.451 \\
\hline EV & 0.144 & 0.671 & 0.278 & 0.281 & 0.874 & 0.201 \\
\hline EWOM & 0.552 & 0.363 & 0.599 & 0.553 & 0.323 & 0.737 \\
\hline
\end{tabular}

Table 5

Heterotrait-Monotrait Ratio

\begin{tabular}{|c|c|c|c|c|c|c|}
\hline & $\mathrm{BD}$ & IQ & REPPUR & Like & EV & EWOM \\
\hline \multicolumn{7}{|l|}{$\mathrm{BD}$} \\
\hline IQ & 0.132 & & & & & \\
\hline REPPUR & 0.101 & 0.290 & & & & \\
\hline Like & 0.144 & 0.323 & 0.216 & & & \\
\hline EV & 0.071 & 0.292 & 0.230 & 0.284 & & \\
\hline EWOM & 0.135 & 0.203 & 0.426 & 0.215 & 0.412 & \\
\hline
\end{tabular}

According to the second criteria for discriminative validity, the loading of each item must be greater than the loading of the equivalent variable (Gefen, Straub, and Boudreau 2000). As a result, Table 5 shows that the second requirement has also been met. The final requirement for discriminative validity is that the HTMT value is less than 0.85 . The third condition is likewise proven is presented in Table 5; ensure that the discriminating validity is recognized.

Table 6

$\mathrm{R}^{2}$ of the endogenous latent variables

\begin{tabular}{lll}
\hline Constructs & $\mathrm{R}^{2}$ & Results \\
\hline $\mathrm{BC}$ & 0.781 & High \\
$\mathrm{PI}$ & 0.694 & High \\
\hline
\end{tabular}

A determination scale (R2 value) is commonly used to assess the structural model (Drip, Basir, \& Fabel 2016). This client is used to determine the predicted accuracy of the model. The correlation between the actual and expected values of a certain eigenvector is squared (Hair et al. 2016). The client implies the effect of the external latent factors on the internal latent variable. The factor is the quadratic correlation between the variables' actual and expected values. Furthermore, it denotes the degree of variety in the internal structures that are reinforced by each external structure associated with them. According to (Chin et al., 2003), when the value is larger than 0.67 , it is considered high; when it is between 0.33 and 0.66 , it is considered to mean; and when it is between 0.19 and 0.66 , it is considered low. The value of 0.33 is seen as insufficient. Similarly, an approximation of less than 0.19 is unacceptable. Table 6 demonstrates that the model has excellent predictive power, accounting for around $79 \%$ and $69 \%$ of the variance in BC and favoritism intent, respectively.

\subsection{Hypotheses test}

SEM-PLS a structural model was utilized to validate the proposed hypotheses and assess the link between theoretical elements (Salloum et al., 2018, 2018). The structural model's results are shown in Table 7 and Fig. 2. According to the findings, all hypotheses are valid. The experimental data supported the hypotheses H1, H2, H3, H4, and H5 based on data analysis. The findings revealed that (SMIs) $(\beta=0.391, \mathrm{P}<0.05)$ and $\mathrm{BC}(\beta=0.277, \mathrm{P}<0.05)$ had a substantial impact on favoritism intent. As a result, H1 and H5 are both supported. Furthermore, BC influenced Likability $(=0.394, \mathrm{P}<0.001)$, the Information quality $(=0.517, \mathrm{P}<0.001)$, and the environment value $(=0.214, \mathrm{P}<0.001)$, supporting $\mathrm{H} 2, \mathrm{H} 3$, and H4. See Table 7 provides an overview of the hypothesis test outcomes. 
On the other side, by Preacher and Hayes (2004), we consider that another test was conducted using Smart PLS to examine the indirect effect of BC on the link between ambient SMI and favoritism intentions. Similarly, the results demonstrate that the indirect impact with $\beta=0.202$ has an t-value of 3.430 and is relevant. Furthermore, the preacher's technique.

The model has significant predictive power, accounting for around $79 \%$ and $69 \%$ of the variance in BC and favoritism intent, respectively.

Table 7

Results of the structural model - Research hypotheses

\begin{tabular}{ccccccc}
\hline$H$ & Relationship & Path & $t$-value & $p$-value & Direction \\
\hline H1 & SMI $\rightarrow$ PI & $\mathbf{0 . 3 9 1}$ & $\mathbf{1 . 3 8 2}$ & $\mathbf{0 . 0 4 1}$ & Positive & Decision \\
H2 & Information quality $\rightarrow$ BC & $\mathbf{0 . 3 9 4}$ & $\mathbf{1 0 . 1 2 1}$ & $\mathbf{0 . 0 0 1}$ & Positive & Supported* \\
H3 & Likability $\rightarrow$ BC & $\mathbf{0 . 5 1 7}$ & $\mathbf{4 . 1 9 2}$ & $\mathbf{0 . 0 1 0}$ & Positive & Supported \\
H4 & Entertainment value $\rightarrow$ BC & $\mathbf{0 . 2 1 4}$ & $\mathbf{6 . 3 1 2}$ & $\mathbf{0 . 0 0 2}$ & Positive & Supported** \\
H5 & $\mathbf{B C} \rightarrow$ PI & $\mathbf{0 . 2 7 7}$ & $\mathbf{2 . 5 3 1}$ & $\mathbf{0 . 0 3 2}$ & Positive & Supported* \\
H6 & SMI $\rightarrow$ BC $\rightarrow$ PI & 0.202 & 3.430 & 0.035 & Positive & Supported*, partial mediation \\
\hline
\end{tabular}

Note: Significant at $\mathrm{p}^{* *}=<0.01, \mathrm{p}^{*}<0.05$

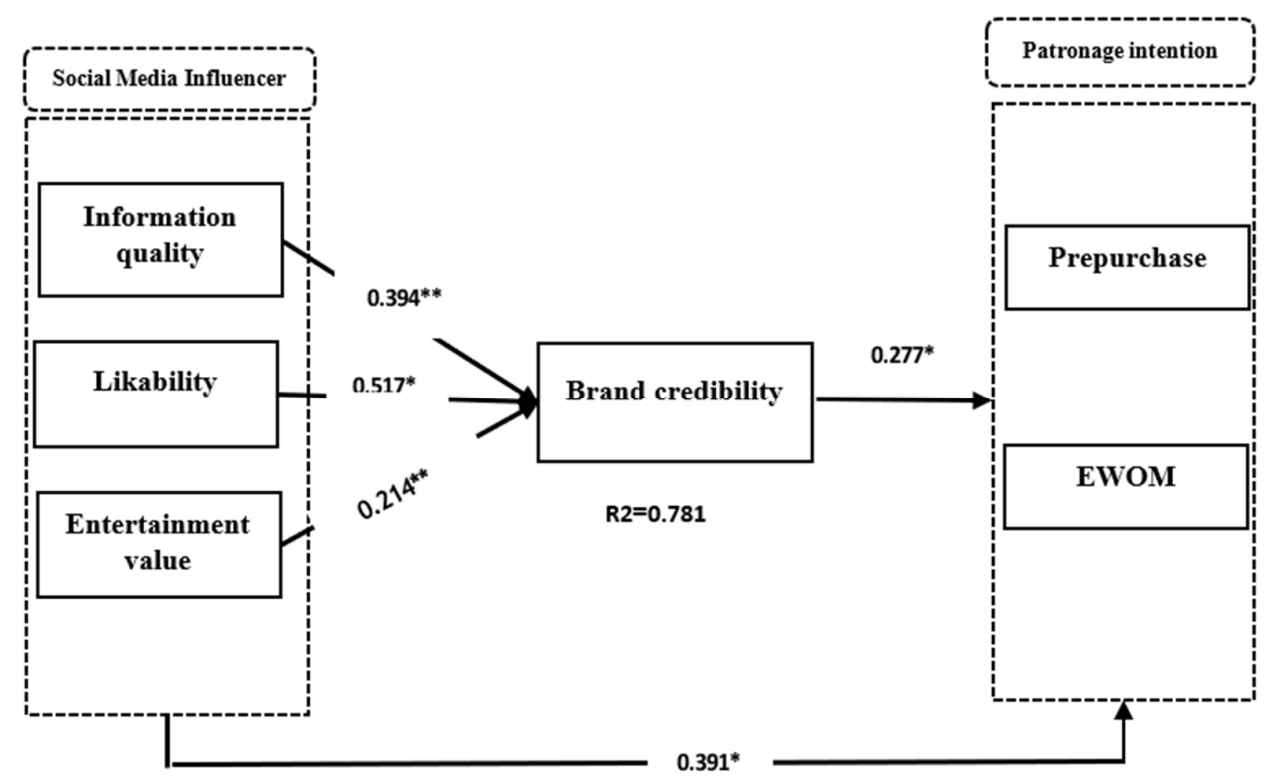

Fig. 2. Path coefficient results (Significant at $\mathrm{p}^{* *} \leq 0.01, \mathrm{p}^{*}<0.05$ ).

\section{Discussion and conclusion}

This article examined the relationship between SMIs and PI, as well as the effect of BC, to use a sample of consumers who follow SMIs. SMIs were measured by three sub-variables: information quality, likeability, and entertainment value; however, PI was determined by EWOM and RP. The study's findings demonstrate that SMIs, whether in terms of information quality, likability, or entertainment value, have higher credibility with their followers, which impacts favorable EWOM and encourages PI. Regarding H1, it is indicated that SMIs have a positive influence on PI in the electronic devices sector. This finding is supported by the findings of Creyer and Ross (1997), who identified a connection between SMI and pi. Nonetheless, the findings of Creyer and Ross (1997) did not link it to any smartphone sector and did not include the same subcomponents as this study did (Information quality, Likability, and Entertainment value). As a result, SMI, in general, adds value to the electronic devices sector, which influences social media followers. This is something that can be observed in real life. As a result of giving the image greater clout, ewom and repeat sales increase. Furthermore, $\mathrm{H} 2$ indicated that information quality has a beneficial influence on brand trustworthiness. A previous study noted the significance of information quality in establishing a brand reputation (Rhee, Ryu, \& Yoon 2006). The findings confirm the favorable impact of information quality on BC. This is especially true in Jordanian, where information quality has a tremendous influence on public opinion. For example, when Yehia Radwan ran his channel, he established credibility with his fans (Moussetis, Abu Rahma, \& Nakos 2005). As a result of that channel's excellent reputation, their followers gained credibility in the same content (smartphone). Evidence demonstrates that SMIs ' activities, when properly presented, will raise brand recognition (Maignan and Ferrell 2004). Furthermore, H3 Likability significantly influences BC in smartphone content; when Likability acts in tandem with SMI activities, they become more trustworthy. Furthermore, the trustworthiness of influencers, such as (Samsung), will have an impact on the brand (Sen et al., 2006). Clarkson (1995) also demonstrated that SMI and likability are related to credibility (Alamro \& Rowley 2011). 
The following H4, Entertainment value, positively affects BC in smartphone content, and this relationship validates the findings of Kim (2017)'s study, which confirms the relationship to a more credible brand. As an example, when Yehia Radwan chose to generate entertainment content to attract followers, such as video games (Obeidat et al. 2016). When a brand is regarded to be practicing 'goodwill' and giving back to a follower, it directly increases the company's reputation.

Finally, H5 was supported, which indicated that BC influences PI s in smartphone content. The findings confirm that BC has a favorable effect on PI, which is consistent with the findings of a prior study by Parasuraman, Zeithaml, and Berry (1988), which found that BC favorably affects buy intentions. As a result, the more trustworthy a business is on social media, particularly on YouTube and Facebook, the more likely it is that followers will purchase and comment positively (ewom) about a certain brand. As a result, greater efforts should be made by influencers and content to strengthen the credibility of the brand, whether it is the quality of a brand, the pricing of a brand, or an SMI activity. How the smartphone content influencer announces and promotes

The action is significant since social media followers follow an influencer without factors Information quality, Likability, and Entertainment value the fact fails to have the desired effect. To the best of our knowledge, the findings of this study, as well as the final hypothesis 5, which proposed that BC acts as a mediator between SMI and PI, were examined for the first time in smartphone content. Then, as competition grows, brands (smartphones) must have a competitive advantage to compete; as a result, they must begin applying marketing concepts such as social media content by influencers as one of the strategies due to the significant effect it has on Ewom and PI.

\section{Implications and future research}

Based on the research empirical findings, from a practical standpoint, this study broadens awareness of the function of SMIs in $\mathrm{BC}$ and $\mathrm{RP}$, and it recommends sharing material to gain greater credibility, impact Ewom, and promote RP. It will increase the number of customers for the brand that benefits the community. Furthermore, socially influential people have become appealing aspects that are being used in a variety of fields of electronic gadgets. A large number of followers, as well as an unexpected surge in the number of influencers, will also aid in this respect. Furthermore, followers of socially driven people who develop engagement around specific material and share that content with companies are more likely to have greater trust and credibility with their followers, which is a primary emphasis of this research. Furthermore, the findings have managerial implications in terms of increasing credibility for followers of this material in the electronics sector via SMIs and engagement. According to the research, the trustworthiness of SMIs influences followers' faith in the material. As a result, the findings indicate that content followers will place higher trust in SMIs about specific material. We urge that firms have a clear strategy and assign a budget to their management to spend in giving roles to SMIs in developing corporate content so that electronic device companies obtain confidence from customers and followers. They should be interested in promoting content on a broad scale in order to increase sales and build credibility. Understanding the impact of corporate SMIs on PI from the perspective of followers can help marketing managers and marketers alike understand how to best build crosscontent content for corporate SMIs. The findings reported in this study are critical for marketing managers and marketers participating in business content generation. They argue that marketing managers and marketers participating in content creation for businesses should target and balance their relationships with influencers, which improves brand reputation. Thus, for organizations to gain credibility, marketing managers and marketers must properly evaluate the power of SMIs. Furthermore, marketing managers and marketers should engage in more activities with a variety of SMIs to boost their reputation, because corporate SMIs have a direct impact on the company's credibility. According to the search results, it is also suggested that businesses build promotional programs that target both their staff and the external audience and consumers.

\subsection{The limitations}

As with all research investigations, several limitations need to be investigated more in the future. To begin generalizing the study's findings, testing this model in other areas and nations will provide useful insights into the function of corporate influencers and PI in different cultures. Second, almost the entire body of work on research of influencers across corporate social media platforms employs the survey method as the primary data gathering tool, both longitudinal and longitudinal.

To investigate the causal relationship between the factors identified here, experimental designs can be used. Third, it can allow for the investigation of various new dimensions and the investigation of their function incorporate customer care intent. Furthermore, marketing executives must place a greater emphasis on the results of defining and implementing a role for corporate social influencers. As a result, subsequent research should consider the critical criteria for investigating such connections. Finally, future studies could compare using a comparative design.

This study contributes to a better understanding of the effect of BC on the links between corporate social influencers and PI.

\section{Acknowledgments}

The authors would like to thank all the participants involved in this research work, and the authors are grateful to the Middle East University, Amman, Jordan for the financial support granted to cover the publication fee of this data article. 


\section{References}

Alrwashdeh, M., Emeagwali, O., \& Aljuhmani, H. (2019). The effect of electronic word of mouth communication on purchase intention and brand image: An applicant smartphone brands in North Cyprus. Management Science Letters, 9(4), $505-518$.

Abreu, R. (2019). Social media micro-infleuncer marketing and purchasing intention of millenials: The role of perceived authenticity and trust [Doctoral dissertation].

Arora, A. S., \& Sanni, S. A. (2019). Ten years of 'social media marketing'research in the Journal of Promotion Management: Research synthesis, emerging themes, and new directions. Journal of Promotion Management, 25(4), 476-499. https://doi.org/10.1080/10496491.2018.1448322

Chakraborty, U., \& Bhat, S. (2018). The Effects of Credible Online Reviews on Brand Equity Dimensions and Its Consequence on Consumer Behavior. Journal of Promotion Management, $24(1)$, 57-82. https://doi.org/10.1080/10496491.2017.1346541

Chen, C. C., \& Lin, Y. C. (2018). What drives live-stream usage intention? The perspectives of flow, entertainment, social interaction, and endorsement. Telematics and Informatics, 35(1), 293-303. https://doi.org/10.1016/j.tele.2017.12.003.

Cheung, C. M. Y., Sia, C. L., \& Kuan, K. K. Y, (2012). Is this review believable? A study of factors affecting the credibility of online consumer reviews from an ELM perspective.

Chin, P. N., Isa, S. M., \& Alodin, Y. (2020). The impact of endorser and brand credibility on consumers' purchase intention: the mediating effect of attitude towards brand and brand credibility. Journal of Marketing Communications, 26(8), 896817. https://doi.org/ 10.1080/13527266.2019.1604561

Chin, W. W., Marcolin, B. L., \& Newsted, P. R. (2003). A partial least squares latent variable modeling approach for measuring interaction effects: Results from a Monte Carlo simulation study and an electronic-mail emotion/adoption study. Information Systems Research, 14(2), 189-217. https://doi.org/10.1287/isre.14.2.189.16018

Costanzo, P. J., \& Goodnight, J. E. (2005). Celebrity endorsements: Matching celebrity and endorsed brand in magazine advertisements. Journal of Promotion Management,11(4),49-62. https://doi.org/10.1300/J057v11n04 05

Dao, W. V. T., Le, A. N. H., Cheng, J. M. S., \& Chen, D. C. (2014). Social media advertising value: The case of transitional economies in Southeast Asia. International Journal of Advertising, 33(2), 271-294. https://doi.org/10.2501/IJA-33-2-271$\underline{294}$

De Veirman, M., Cauberghe, V., \& Hudders, L. (2017). Marketing through instagram influencers: The impact of number of followers and product divergence on brand attitude. International Journal of Advertising, 36(5), 798-828. https://doi.org/10.1080/02650487. 2017.1348035

De Vries, L., Gensler, S., \& Leeflang, P. S. H. (2012). Popularity of Brand Posts on Brand Fan Pages: An Investigation of the Effects of Social Media Marketing. Journal of Interactive Marketing, $26(2), \quad 83-91$. https://doi.org/10.1016/j.intmar.2012.01.003

Desarbo, W. S., \& Harshman, R. A. (1985). Celebrity-brand congruence analysis. Current Issues and Research in Advertising, 8(1), 17-52. https://doi.org/10.1080/01633392.1985.10505371

Dinev, T., \& Hart, P. (2004). Internet privacy concerns and their antecedents-measurement validity and a regression model. Behaviour \& Information Technology, 23(6),413-422. https://doi.org/10.1080/01449290410001715723

Djafarova, E., \& Rushworth, C. (2017). Exploring the credibility of online celebrities' Instagram profiles in influencing the purchase decisions of young female users. Computers in Human Behavior, 68, 1-7. https://doi.org/10.1016/i.chb.2016.11.009

Dodoo, N. A. (2018). Why Consumers Like Facebook Brands: The Role of Aspirational Brand Personality in Consumer Behavior. Journal of Promotion Management, 24(1),103-127. https://doi.org/10.1080/10496491.2017.1346536

Ducoffe, R. H. (1996). Advertising value and advertising on the web. Journal of Advertising Research, 36(5), 21-35.

Fornell, C., \& Larcker, D. F. (1981). Evaluating Structural Equation Models with Unobservable Variables and Measurement Error. Journal of Marketing Research, 18(1), 39-5 https://doi.org/10.1177/002224378101800104

Freberg, K., Graham, K., McGaughey, K., \& Freberg, L. A. (2011). Who are the social media influencers? A study of public perceptions of personality. Public Relations Review, 37(1), 90-92. https://doi.org/10.1016/j.pubrev.2010.11.001

Gass, R., \& Seiter, J. (2011). Persuasion, social influence and compliance gaining, 4e ed.

Gautam, V., \& Sharma, V. (2017). The Mediating Role of Customer Relationship on the Social Media Marketing and Purchase Intention Relationship with Special Reference to Luxury Fashion Brands. Journal of Promotion Management, 23(6), 872888. https://doi.org/10.1080/10496491.2017.132326

Godey, B., Manthiou, A., Pederzoli, D., Rokka, J., Aiello, G., Donvito, R., \& Singh, R. (2016). Social media marketing efforts of luxury brands: Influence on brand equity and consumer behavior. Journal of Business Research, 69(12), 5833-5841. https://doi.org/10.1016/j.jbusres.2016.04.181

Hair, J. F., Jr, \& Lukas, B. (2014). Marketing research. (Vol. 2). McGraw-Hill Education.

Hair, J. F., Hult, G. T. M., Ringle, C. M., Sarstedt, M., \& Thiele, K. O. (2017). Mirror, mirror on the wall: a comparative evaluation of composite-based structural equation modeling methods. Journal of the Academy of Marketing Science, 45(5), 616-632. https://doi.org/10.1007/s11747-017-0517-x

Hair, J. F., Ringle, C. M., \& Sarstedt, M. (2013). Partial Least Squares Structural Equation Modeling: Rigorous Applications, Better Results and Higher Acceptance. Long Range Planning, 46(1-2), 1-12. https://doi.org/10.1016/j.lrp.2013.01.001 
Hayes, R. A., \& Carr, C. T. (2015). Does Being Social Matter? Effects of Enabled Commenting on Credibility and Brand Attitude in Social Media. Journal of Promotion Management, 21(3), 371-390. https://doi.org/10.1080/10496491.2015.1039178

$\mathrm{Hu}$, X., Lin, Z., \& Zhang, H. (2003). Trust promoting seals in electronic markets: An exploratory study of their effectiveness for online sales promotion. Journal of Promotion Management, 9(1-2), 163-180. https://doi.org/10.1300/J057v09n01_13

Kim, A. J., \& Ko, E. (2012). Do social media marketing activities enhance customer equity? An empirical study of luxury fashion brand. Journal of Business Research, 65(10),1480-1486. https://doi.org/10.1016/j.jbusres.2011.10.014

Kumar, A. (2011). Celebrity Endorsements and Its Impact on Consumer Buying Behaviour. SSRN Electronic Journal, https://doi.org/10.2139/ssrn.1802531

Kumar, S., Spais, G. S., Kumar, D., \& Sureka, R. (2020). A bibliometric history of the journal of promotion management (1992-2019). Journal of Promotion Management, 26(1), 97-120. https://doi.org/10.1080/10496491.2019.1685622

La Ferle, C., \& Choi, S. M. (2005). The importance of perceived endorser credibility in south korean advertising. Journal of Current Issues \& Research in Advertising, 27(2), 67-81. https://doi.org/10.1080/10641734.2005.10505182

Leung, L. (2013). Generational differences in content generation in social media: The roles of the gratifications sought and of narcissism. Computers in Human Behavior, 29(3), 997-1006. https://doi.org/10.1016/j.chb.2012.12.028

Lou, C., \& Yuan, S. (2019). Influencer Marketing: How Message Value and Credibility Affect Consumer Trust of Branded Content on Social Media. Journal of Interactive Advertising, 19(1), 58-73. https://doi.org/10.1080/15252019.2018.1533501

O'Keefe, D. J. (1990). Persuasion: Theory and research. Sage. https://www.scholars.northwestern.edu/en/publications/persuasion-theory-and-research-2 Ohanian, R. (1990). Construction and validation of a scale to measure celebrity endorsers' perceived expertise, trustworthiness, and attractiveness. Journal of Advertising, 19(3), 39-52. https://doi.org/10.1080/00913367.1990.10673191

Ohanian, R. (1991). The impact of celebrity spokespersons' perceived image on consumers' intention to purchase. Journal of Advertising Research, 31(1), 4654.

Pina, L. S., Loureiro, S. M. C., Rita, P., Sarmento, E. M., Bilro, R. G., \& Guerreiro, J.(2019). Analysing Consumer-Brand Engagement Through Appreciative Listening on Social Network Platforms. Journal of Promotion Management, 25(3), 304-313. https://doi. org/10.1080/10496491.2019.1557805

Statista (2020). Number of social network users in India from 2015 to 2018 with a forecast until 2023. Retrieved July 4, 2020, from https://www.statista.com/statistics/278407/number-of-social-network-users-in-india/

Statista (2020). Social media usage in India - statistics \& facts. https://www.statista.com/ topics/5113/social-media-usage-inindia/ Retrieved August 7, 2020, from https:/www.statista.com/topics/5113/social-media-usage-in-india/

Taylor, D. G., Lewin, J. E., \& Strutton, D. (2011). Friends, fans, and followers: Do ads work on social networks? How gender and age shape receptivity. Journal of Advertising Research, 51(1), 258-276. https://doi.org/10.2501/JAR-51-1-258-275

Trivedi, J., \& Sama, R. (2020). The Effect of Influencer Marketing on Consumers' Brand Admiration and Online Purchase Intentions: An Emerging Market Perspective. Journal of Internet Commerce, 19(1), 103-124. https://doi.org/10.1080/15332861.2019.1700741

Voss, K. E., Spangenberg, E. R., \& Grohmann, B. (2003). Measuring the Hedonic and Utilitarian Dimensions of Consumer Attitude. Journal of Marketing Research, 40(3), 310-320. https://doi.org/10.1509/jmkr.40.3.310.19238

Wang, S. W., Kao, G. H. Y., \& Ngamsiriudom, W. (2017). Consumers' attitude of endorser credibility, brand and intention with respect to celebrity endorsement of the airline sector. Journal of Air Transport Management, 60, 10-17.

https://doi.org/10.1016/j.jairtraman.2016.12.007

Xiao, M., Wang, R., \& Chan-Olmsted, S. (2018). Factors affecting YouTube influencer marketing credibility: a heuristicsystematic model. Journal of Media Business Studies, 15(3), 188-213.

https://doi.org/10.1080/16522354.2018.1501146

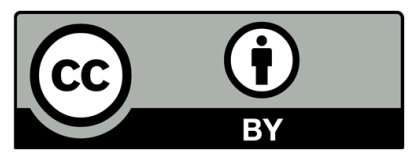

(C) 2022 by the authors; licensee Growing Science, Canada. This is an open access article distributed under the terms and conditions of the Creative Commons Attribution (CC-BY). license (http://creativecommons.org/licenses/by/4.0/). 